\title{
ILEAL HERNIATION THROUGH THE FORAMEN OF WINSLOW: OVEREATING AS A RISK FACTOR FOR INTERNAL HERNIATION
}

\author{
Lora Stanka Kirigin ${ }^{1}$, Marko Nikolić ${ }^{2}$, Ivan Kruljac², Domagoj Marjan ${ }^{3}$, Ivan Penavić ${ }^{4}$, Neven Ljubičić ${ }^{1}$, \\ Ivan Budimir ${ }^{2}$ and Milan Vrkljan ${ }^{1}$
}

\begin{abstract}
${ }^{1}$ Mladen Sekso Department of Endocrinology, Diabetology and Metabolic Diseases, ${ }^{2}$ Department of Gastroenterology and Hepatology, ${ }^{3}$ Department of Radiology, ${ }^{4}$ Department of Abdominal Surgery, Sestre milosrdnice University Hospital Center, Zagreb, Croatia
\end{abstract}

\begin{abstract}
SUMMARY - Internal hernias have an overall incidence of less than $1 \%$ and are difficult to diagnose clinically due to their nonspecific presentation. Most internal hernias present as strangulating closed-loop obstruction and delay in surgical intervention is responsible for a high mortality rate (49\%). We present a case of ileal herniation through the foramen of Winslow. A 29-year-old previously healthy female presented with acute onset right upper quadrant pain, abdominal fullness, and nausea. The pain was sudden in onset and began shortly after a dinner party where she consumed larger portions of food. Laboratory investigations revealed mild leukocytosis with left shift. Dual-phase multi-detector computed tomography disclosed herniation of the small bowel into the lesser sac. The patient underwent an emergency median laparotomy that revealed ileal herniation through the foramen of Winslow. Adhesiolysis and manual reduction of the bowel was performed, and the reduced bowel showed only congestive changes. The postoperative recovery was uneventful and the patient was discharged on the third postoperative day. Risk factors for internal herniation still remain unclear, although excessively mobile bowel loops and an enlarged foramen of Winslow have been described. Our case demonstrated that overeating could be an additional risk factor for internal herniation. We describe our clinical and radiology findings, as well as surgical management. Due to the high rates of morbidity and mortality, it is imperative that clinicians be aware of the possible risks factors for internal herniation. Internal hernias should be included in the differential diagnosis of small bowel obstruction so that appropriate steps can be made in the work-up of these patients, followed by timely surgical intervention.
\end{abstract}

Key words: Abdomen, acute; Hernia, abdominal - surgery; Herniorrbaphy - methods; Ileal diseases surgery; Hyperphagia; Case reports

\section{Introduction}

Internal hernias have an overall incidence of less than $1 \%$, and are responsible for $0.5 \%-4.1 \%$ of cases of intestinal obstruction ${ }^{1,2}$. They have a nonspecific

Correspondence to: Lora Kirigin, MD, Mladen Sekso Department of Endocrinology, Diabetology and Metabolic Diseases, Sestre milosrdnice University Hospital Center, Vinogradska c. 29, HR-10000 Zagreb, Croatia

E-mail: lora.s.kirigin@gmail.com

Received May 19, 2015, accepted July 1, 2015 clinical presentation and only $10 \%$ are diagnosed preoperatively. When they do become clinically apparent, it is usually after incarceration from small bowel obstruction ( $\mathrm{SBO}$ ) has occurred. By this time, there is an increased risk of severe complications, and the mortality rate is reported to be as high as $50 \% 1$.

Internal hernias occur when a viscus protrudes through a normal or abnormal peritoneal opening. The foramen of Winslow is a normal communication between the lesser sac and the greater peritoneal cavity and has a diameter of $3 \mathrm{~cm}$. It lies anteriorly to the 
inferior vena cava and posteriorly to the hepatoduodenal ligament. Its superior and inferior boundaries include the caudate lobe of the liver and duodenum, respectively ${ }^{1,2,4}$.

The various types of internal hernias and their frequencies include paraduodenal (53\%), pericecal (13\%), foramen of Winslow (8\%), transmesenteric and transmesocolic (8\%), pelvic and supravesical (6\%), sigmoid mesocolon $(6 \%)$ and transomental $(1 \%-4 \%)^{1,2}$.

Small intestine is the herniated organ in 60\%-70\% of cases. Other herniated contents including the cecum, distal ileum and ascending colon occur in 25\%$30 \%$ of cases. Herniation of transverse colon and gallbladder is rarely reported ${ }^{2}$.

Risk factors for internal herniation still remain unclear; however, a few have been suggested and include excessively mobile bowel loops and an enlarged foramen of Winslow ${ }^{5}$. Mobile intestinal loops can occur as a result of a long small bowel mesentery, persistence of the ascending mesocolon and an ascending colon that has not fused with the parietal peritoneum ${ }^{1,2}$. Sudden increases in intra-abdominal pressure such as childbirth or heavy lifting can also contribute to herniation ${ }^{1,6}$.

The clinical presentation of internal hernias is nonspecific and can present differently in each patient. The severity of pain usually correlates with the degree of bowel incarceration and strangulation. Internal hernias most commonly present as acute small bowel obstruction with severe pain, abdominal distention and vomiting. However, if the hernia is able to reduce spontaneously, the pain may be mild and transitor $y^{1-4,7}$. During this time, physical and clinical examination may be unremarkable ${ }^{2,7}$. Although seen less commonly, the herniated segment may compress the common bile duct leading to jaundice and a distended gallbladder ${ }^{1}$.

Most internal hernias present as strangulated closed-loop obstruction and timely diagnosis is essential to prevent adverse outcomes ${ }^{2}$. Several authors have described the findings of conventional radiographs ${ }^{6}$. Most commonly, distended bowel loops with air-fluid levels are seen in the middle upper abdomen, medially and posteriorly to the stomach ${ }^{1,2,4,7}$. If the ascending colon and cecum are involved, the right iliac fossa will appear empty ${ }^{2,6,7}$. Due to the mass effect of the distended bowel, the stomach is usually displaced laterally and anteriorly ${ }^{4,6}$.

Computed tomography (CT) is the optimal imaging technique when assessing $\mathrm{SBO}$ and has been shown to be $83 \%-94 \%$ accurate in the diagnosis of this condition ${ }^{2,8}$. Unfortunately, there is limited literature that describes $\mathrm{CT}$ findings of hernias through the foramen of Winslow ${ }^{2}$. Some features include (a) a collection of dilated bowel with air-fluid levels in the lesser sac; (b) mesentery between the inferior vena cava and portal vein; (c) absence of the ascending mesocolon in the right iliac fossa; and (d) two or more bowel loops in the high subhepatic spaces ${ }^{2,7,9,10}$.

We report a case of ileal herniation through the foramen of Winslow that occurred following a large meal. The patient was diagnosed using multi-detector $\mathrm{CT}$ and was treated with prompt surgical reduction.

\section{Case Report}

A 29-year-old previously healthy female presented to the Emergency Department (ED) with a 7-hour history of right upper quadrant pain, abdominal fullness and nausea. She had no history of prior abdominal surgery and her past medical history included well-controlled epilepsy. The pain was sudden in onset and began shortly after a dinner party where she had consumed larger portions of food. The pain was constant and progressive with radiation to her back. On the day of presentation, she was obstipated but was able to pass flatus. The patient recalled that one week earlier, she had experienced a similar quality of pain. It was of lower intensity and had passed spontaneously. On examination, the patient's vital parameters were within the acceptable limits (body mass index $22 \mathrm{~kg} / \mathrm{m}^{2}$; blood pressure 115/70; pulse 80 ; respiratory rate 15 ; temperature $36.7^{\circ} \mathrm{C}$ ). Physical examination revealed tenderness in the epigastrium and right upper quadrant after deep palpation. Guarding and peritoneal signs were absent. There was minimal abdominal distention and preserved bowel sounds. Laboratory investigations revealed mild leukocytosis $\left(10.7 \times 10^{9} / \mathrm{L}\right.$, reference range: $3.4-9.7 \times 10^{9} / \mathrm{L}$ ) and elevated neutrophil count (7.40x10 $/ \mathrm{L}$, reference range: $\left.2.06-6.49 \times 10^{9} / \mathrm{L}\right)$. All other laboratory investigations including $\mathrm{C}$-reactive protein (CRP; $0.4 \mathrm{mg} / \mathrm{L}$, reference range: $<5.0)$ fell within the normal range. The patient was admit- 
ted and treated with IV hydration, analgesia, and anti-emetics. During observation, the patient's pain progressed and she began to vomit. Plain abdominal films were ordered and revealed dilated small bowel loops with air-fluid levels in the right upper quadrant of the abdomen (Fig. 1). Trans-abdominal ultrasound also revealed dilated small bowel loops. Dualphase multi-detector CT (MDCT) with oral contrast disclosed herniation of the small bowel into the lesser sac (Fig. 2). Repeat laboratory tests revealed a leukocyte rise to $18.3 \times 10^{9} / \mathrm{L}$ (reference range: $3.4-$ $\left.9.7 \times 10^{9} / \mathrm{L}\right)$ with neutrophil count of $16.10 \times 10^{9} / \mathrm{L}$ (reference range: $2.06-6.49 \times 10^{9} / \mathrm{L}$ ) and normal CRP $(4.0 \mathrm{mg} / \mathrm{L}$, reference range: $<5.0 \mathrm{mg} / \mathrm{L})$. Surgery was consulted and the patient underwent an emergency median laparotomy approximately 16 hours after initial presentation. During surgical exploration, small bowel obstruction due to herniation through the foramen of Winslow was confirmed. Approximately 10 $\mathrm{cm}$ of the distal ileum was found herniating through the foramen. Proximal bowel loops were distended to approximately $4-5 \mathrm{~cm}$ and distal loops were collapsed. Adhesions were seen extending from the duodenum to the liver and gallbladder. Adhesions were also felt in the lesser sac and made manual reduction difficult. Nasogastric decompression was performed and the bowel was reduced manually. The reduced bowel loops were viable and showed only congestive changes. The adhesions were then resected and the foramen of Winslow was left open. The postoperative recovery was uneventful and the patient was discharged on the third postoperative day.

\section{Discussion}

Our case demonstrates that overeating could be an additional independent risk factor for internal herniation. The influx of high quantities of food increases peristalsis and could propel the bowel into the lesser sac. The incidence of internal hernias has increased in the past decade due to the rising bariatric practices that distort the normal peritoneal anatomy. In the bariatric population, over half of all cases of small bowel obstruction result from internal herniation ${ }^{1}$.

Our patient presented with typical signs of small bowel obstruction, including abdominal pain, nausea, and vomiting. However, her pain was only moderate and she had minimal abdominal distention with absent peritoneal signs. Since her clinical presentation was nonspecific and laboratory studies were unremarkable, we decided to observe her. In our case, the diagnostic delay did not result in complications. Our patient described a similar episode of pain one week prior to her presentation to the ED. This may have been due to herniation and spontaneous reduction.

Plain radiographs in our patient had similar characteristics to those previously described ${ }^{1,2,4,7}$. Distended small bowel loops with air-fluid levels were seen in the right upper quadrant (Fig. 1). CT imaging revealed dilated small bowel loops in the lesser sac (Fig. 2). CT imaging also revealed stretched mesenteric vessels below the entrapped ileal loop (Fig. 3).

Due to the infrequency of these hernias, there is no consensus regarding correct surgical management $^{10}$. Bowel resection is required in up to $64 \%$ of cases $^{7}$. In our case, the bowel was viable and did not require surgical resection. Our patient did not have an

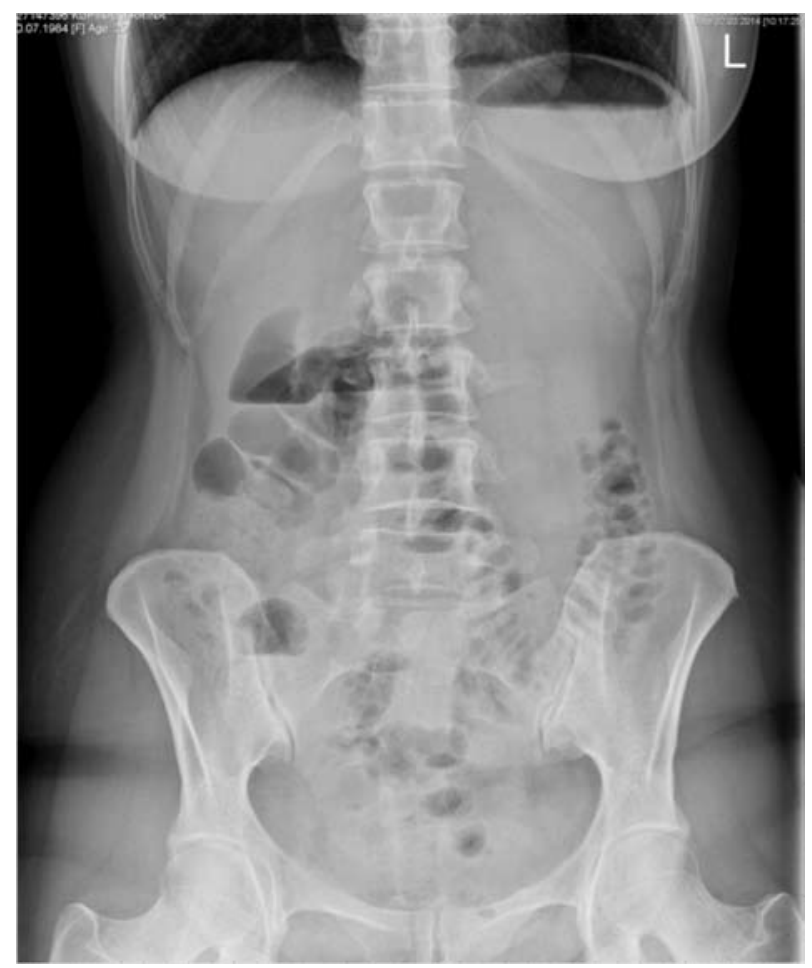

Fig. 1. Plain abdominal $x$-ray shows gas-containing small bowel loops with air-fluid levels in the right upper quadrant. 


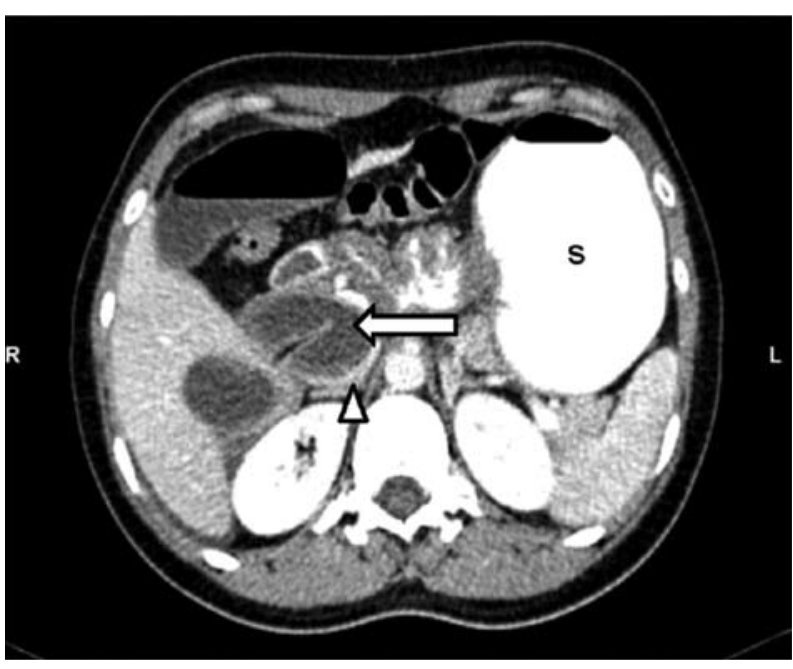

Fig. 2. Contrast-enhanced axial CT shows distended stomach that has been displaced laterally. Small bowel loops are seen in the lesser sac (arrow), between the liver bilum anteriorly and inferior vena cava posteriorly. Distended bowel is compressing the inferior vena cava (arrowhead).

enlarged foramen, and we decided to leave it open. It has been suggested that closure of the foramen may damage portal vessels and this supported our decision. Furthermore, recurrences have rarely been described ${ }^{5}$. We believe that the adhesions seen in our patient were an incidental finding of a normal anatomic variant and did not trigger herniation. However, the adhesions present in the lesser sac were compressing the distended bowel and we had a difficult time reducing it. We did not attempt to resect these adhesions while they were entrapping the bowel in order to avoid accidental perforation. The adhesions were excised only after the bowel was reduced.

\section{Conclusion}

In conclusion, due to the high rates of morbidity and mortality, it is imperative that clinicians be aware of the possible risks factors for internal herniation. Overeating may be an independent risk factor for internal herniation. Internal hernias should be included in the differential diagnosis of SBO, so that early radiological evaluation and surgical treatment can be employed.

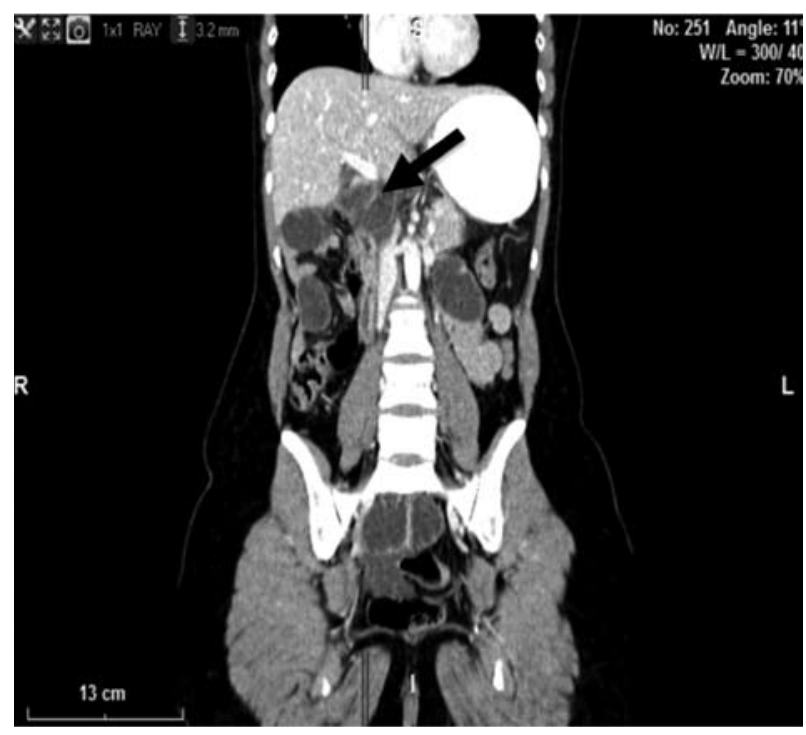

Fig. 3. Contrast-enhanced coronal CT showing distended small bowel loops (arrowhead) and stretched mesenteric vessels below the entrapped ileal loop.

\section{References}

1. Martin LC, Merkle EM, Thompson WM. Review of internal hernias: radiographic and clinical findings. Am J Roentgenol. 2006;186:703-17. doi: 10.2214/AJR.05.0644.

2. Takeyama N, Gokan T, Ohgiya Y, Satoh S, Hashizume T, Hataya K, Kushiro H, Nakanishi M, Kusano M, Munechika H. CT of internal hernias. Radiographics. 2005;4:997-1015. doi: $10.1148 / \mathrm{rg} .254045035$.

3. Sikiminywa-Kambale P, Anaye A, Roulet D, Pezzetta E. Internal hernia through the foramen of Winslow: a diagnosis to consider in moderate epigastric pain. J Surg Case Reports [Internet]. 2014;2014(6):rju065-rju065. Available from: http://jscr.oxfordjournals.org/cgi/doi/10.1093/jscr/rju065

4. Mathieu D, Luciani A. Internal abdominal herniations. AJR Am J Roentgenol [Internet]. 2004 Aug [cited 2016 Mar 9];183(2):397-404. Available from: http://www.ncbi.nlm. nih.gov/pubmed/15269032

5. Powell-Brett SF, Royle JT, Stone T, Clarke RG. Caecum herniation through the foramen of Winslow. J Surg Case Reports [Internet]. 2012;2012:3-5.

6. Forbes SS, Stephen WJ. Herniation through the foramen of Winslow: radiographic and intraoperative findings. Can J Surg. 2006;49:362-3.

7. Lin WC, Lin CH, Lo YP, Liao YH. Rapid pre-operative diagnosis of ileal hernia through the foramen of Winslow with multi-detector computed tomography enabling successful laparoscopic reduction. S Afr J Surg. 2013;51:31-7. 
8. Maung AA, Johnson DC, Piper GL, Barbosa RR, Rowell SE, Bokhari F, Collins JN, Gordon JR, Ra JH, Kerwin AJ. Evaluation and management of small-bowel obstruction: an Eastern Association for the Surgery of Trauma practice management guidelines. J Trauma Acute Care Surg. 2012;73:362-9. doi:10.1097/TA.0b013e31827019de.
9. Selcuk D, Kantarci, F, Ogut G, Korman U. Radiological evaluation of internal hernias. Turk J Gastroenterol. 2005;16:57-64.

10. Puig CA, Lillegard JB, Fisher JE, Schiller HJ. Hernia of cecum and ascending colon through the foramen of Winslow. Int J Surg Case Rep. 2013;4:879-81.

Sažetak

\section{ILEALNA HERNIJACIJA KROZ FORAMEN WINSLOW: PREJEDANJE KAO RIZIČNI ČIMBENIK UNUTARNJE HERNIJE}

\section{Kirigin, M. Nikolic, I. Kruljac, D. Marjan, I. Penavić, N. Ljubičic, I. Budimir i M. Vrkljan}

Ukupna incidencija unutarnjih hernija manja je od 1\%, a zbog njihove nespecifične prezentacije otežano je postavljanje kliničke dijagnoze. Većina unutarnjih hernija prezentira se kao strangulirajuće opstrukcije zatvorene petlje, a nepravodobna kirurška intervencija odgovorna je za visoku stopu smrtnosti (49\%). U našem radu predstavljamo slučaj ilealne hernijacije kroz foramen Winslow. Dvadesetdevetgodišnja prethodno zdrava žena primljena je zbog akutnog nastupa boli locirane u desnom gornjem trbušnom kvadrantu praćene mučninom i osjećajem nadutosti. Bol je nastupila iznenadno, nedugo nakon večere gdje je konzumirala veću količinu hrane. Laboratorijske pretrage pokazale su blagu leukocitozu sa skretanjem ulijevo. Nativnim abdomenom vizualizirani su aerolikvidni nivoi, a višeslojnom kompjutorskom tomografijom prikazana je hernijacija tankog crijeva u omentalnu bursu. Bolesnica je podvrguta hitnoj medijanoj laparotomiji kojom je vizualizirana ilealna hernijacija kroz foramen Winslow. Odstranjene su priraslice s tankoga crijeva koje je pokazivalo promjene kongestivnog tipa. Poslijeoperacijski tijek protekao je uredno te je bolesnica otpuštena kući trećeg dana poslije operacije. Međutim, čimbenici rizika za unutarnje hernijacije još uvijek ostaju nepoznati. Neki od mogućih čimbenika rizika su povećana mobilnost crijevnih vijuga i povećan foramen Winslow. Naš slučaj pokazuje da i prejedanje može biti potencijalni dodatni rizični čimbenik za unutarnje hernijacije. U radu prikazujemo kliničke i radiološke pokazatelje, kao i samu kiruršku intervenciju. Zbog visoke stope pobola i smrtnosti veoma je važno da liječnici budu svjesni mogućih rizičnih čimbenika za pojavu unutarnje hernijacije. U diferencijalnu dijagnostiku opstrukcija tankog crijeva svakako bi trebalo uključiti i unutarnje hernije kako bi se mogle provesti odgovarajuće mjere pri obradi bolesnika te pravodobna kirurška intervencija.

Ključne riječi: Abdomen, akutni; Hernija, abdominalna - kirurgija; Herniorafija - metode; Ileus, bolesti - kirurgija; Prejedanje; Prikazi slučaja 